36. On Spiders of the Family Salticidæ collected by the British Ornithologists' Union Expedition and the Wollaston Expedition in Dutch New Guinea. By H. R. Hogg, M.A., F.Z.S.

[Received and Read May 25, 1915.$]$

\title{
(Text-figures 1-11.)
}

\section{INDEx.}

Boethoportia ocellata, gen. et sp. n.

Diolenius albopiceus, sp. $\mathrm{n}$.

Telamonia vidua, sp. n.

T. mandibulata, sp. n.

Jotus igneus, sp. n.

Plexippus paykullii

Zenodorus d'urvillii .

$Z$. danae, sp. n.

Z. rhodope, sp. n

Z. syrin $x$, sp. 11

Mopsus mormon

Bathippus montrouzieri var. papuanus ............... 522

Hasarius glaucus, sp. n. ............................. 523

Cytaa sylvia, sp. n. ................................. 524

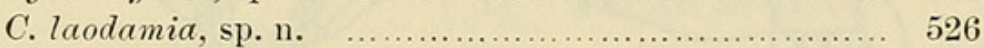

Page

505

508

510

512

513

514

517

519

22

The spiders herein described complete the record of the collections made by the above named Expeditions kindly entrusted by the promoters to my care. The paper in which I described the bulk of the collection appeared in Vol. XX. Part 14, of the Transactions of this Society.

This interesting addition to our previous knowledge includes some very beautiful forms of the exquisitely spangled varieties which in their small bodies rival the coloration of the brilliant bird fauna in which New Guinea is so rich. In spite of the considerable amount of work devoted of late years by many able contributors to collections brought from that country, it is evident that much remains for future explorers before its numerous species are exhausted. The proportion of new forms to those already known among these is about three to one.

\section{Family S A L T I C I D Æ.}

Section Pleuridentati.

Group Bontheж.

Boethoportia, gen. nov.

Boethoportia differs from Portia Karsch in having the front row of eyes straight along the upper edges and the rear row as 
wide as the front row, and from Boetheus in having the femur, patella, and tibia of the first pair of legs stouter than the others, fimbriations of long bristles at least on the tibia of the same, and the metatarsi and tarsi of all legs very fine, the former at least as lon $r$ as the tibiæ.

Boethoportia ocellata, sp. n. (Text-fig. 1.)

1 male and 1 female. (Types of the species.)

Female. The cephalothorax is bright chestnut-red, black round the eyes with sparse white hairs; mandibles red-brown with pale red fangs; lip and maxillæ red-brown, paler at the front edges, with yellowish-grey fringes. Sternum also red-brown with

Text-figure 1 .
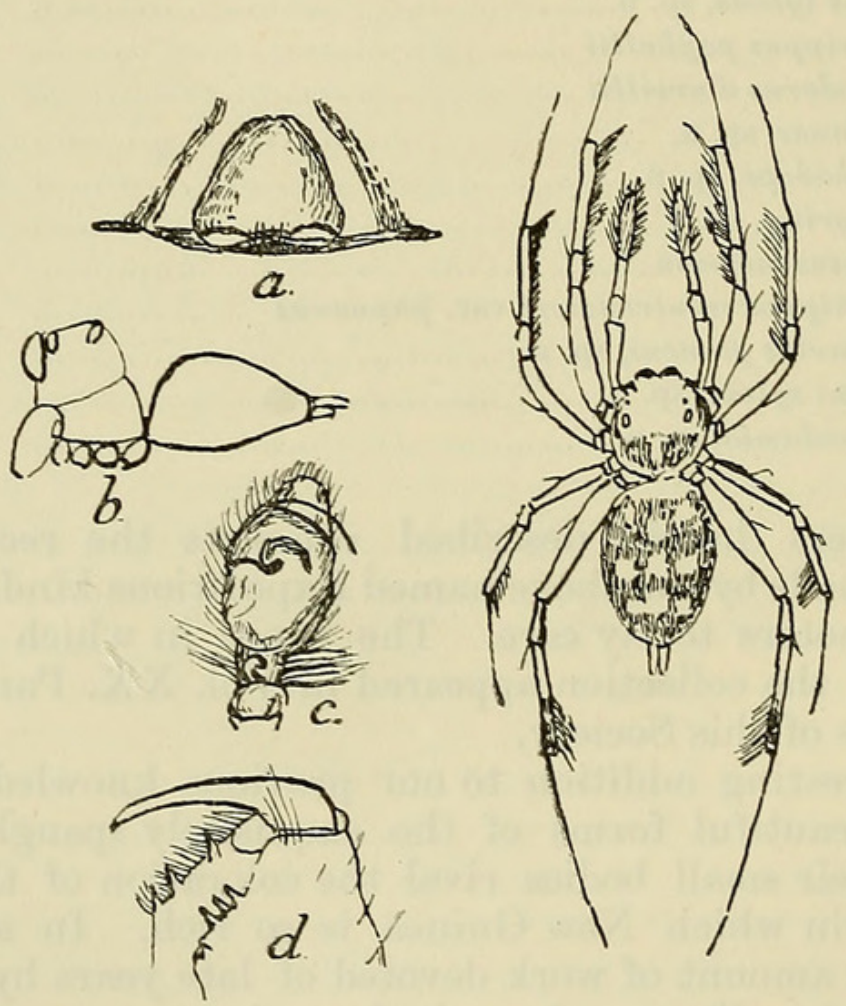

Boethoportia ocellata, gen. et sp. n., $q$.

$a$., epigyne; $b$., profile; $c$., male palp ; $d$., mandible showing teeth.

yellowish-grey hair. Coxæ red-brown; femora brown underneath, with yellow patches on the upper side; tibia brown, with a yellow band in the middle and long brown bristly fringes. Metatarsus and tarsus yellow, with here and there patches of white hair. The abdomen pale yellow at the base, the remainder with large greyish-yellow spots on a brown gound; the underside is also brown with yellow spots, the hairs greyish-yellow on the pale parts, brown on the darker portions.

The cephalic part of the cephalothorax is flat over the eye-space, 
slightly sloping forwards, from the eyes it slopes steeply down to the margin at the sides and rear. The thoracic part is barely one-half the length of the cephalic, and the rear slope is deeper than the whole length of the cephalothorax.

The front median eyes project forward on black rims. They are three times the diameter of the laterals, which stand back somewhat, but are level with the former along the upper margins. The eyes of the rear row are of the same size as the front laterals. The usually small eyes of the median row have a diameter twothirds the length of these; they are rather nearer to the front lateral than to the rear eyes and are somewhat closer together than either.

The abdomen is broadly ovate, straight and widest in front; the spinnerets are terminal, the superior having a conical second joint. The epigyne is roughly triangular, rounder at the apex and incurved in the middle of the base-line, with horizontal oval apertures at the lower corners.

Male. Similarly coloured to the female.

The measurements (in millimetres) are as follows :-

Female.

Long. Broad.

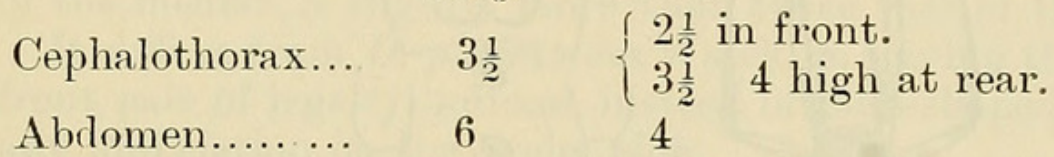

Mandibles $\ldots . . . \quad 2$

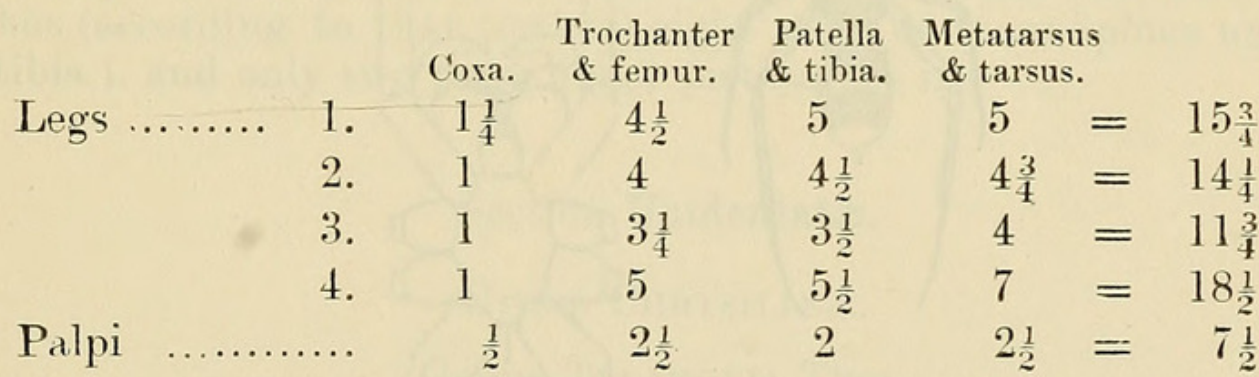

Male.

$\begin{array}{lcc} & \text { Long. } & \text { Bread. } \\ \text { Cephalothorax... } & 3 & 2 \frac{1}{2} \\ \text { Abdomen ......... } & 4 & 1 \frac{3}{4} \\ \text { Mandibles ...... } & 1 \frac{1}{2} & \end{array}$

\begin{tabular}{|c|c|c|c|c|c|c|c|}
\hline \multirow{5}{*}{ Legs .......... } & & Coxa. & Tr. \& fem. & $\&$ tib. & $\& \operatorname{tar}$ & & \\
\hline & 1. & $\frac{3}{4}$ & $3 \frac{1}{2}$ & 4 & 4 & $=$ & $12 \frac{1}{4}$ \\
\hline & 2. & $\frac{3}{4}$ & 3 & $3 \frac{1}{2}$ & $3 \frac{3}{4}$ & $=$ & 11 \\
\hline & 3. & $\frac{3}{4}$ & $2 \frac{1}{2}$ & 3 & 3 & $=$ & $9 \frac{1}{4}$ \\
\hline & 4. & 1 & $3 \frac{1}{2}$ & 4 & 6 & $=$ & $14 \frac{1}{2}$ \\
\hline lpi & 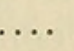 & $\frac{1}{2}$ & $1 \frac{1}{2}$ & $\frac{1}{2}$ & $1 \frac{1}{2}$ & $=$ & 4 \\
\hline
\end{tabular}




\section{Group Dioleniex.}

Genus Diolenius Thor.

Thorell, European Spiders, 1870, p. 203.

E. Simon, Hist. Nat. des Ar. vol. ii. 1901, p. 480.

Diolenius albopiceus, sp. n. (Text-fig. 2.)

1 female. (Type of the species.)

Female. The ground-colour of the cephalic part is black-brown with white hair at the sides and round the eyes, greyer and finer inside the eye-square. The outer margin of the thoracic part is dark yellow-brown, but across the middle is a broad white-haired transverse stripe.

Text-figure 2.

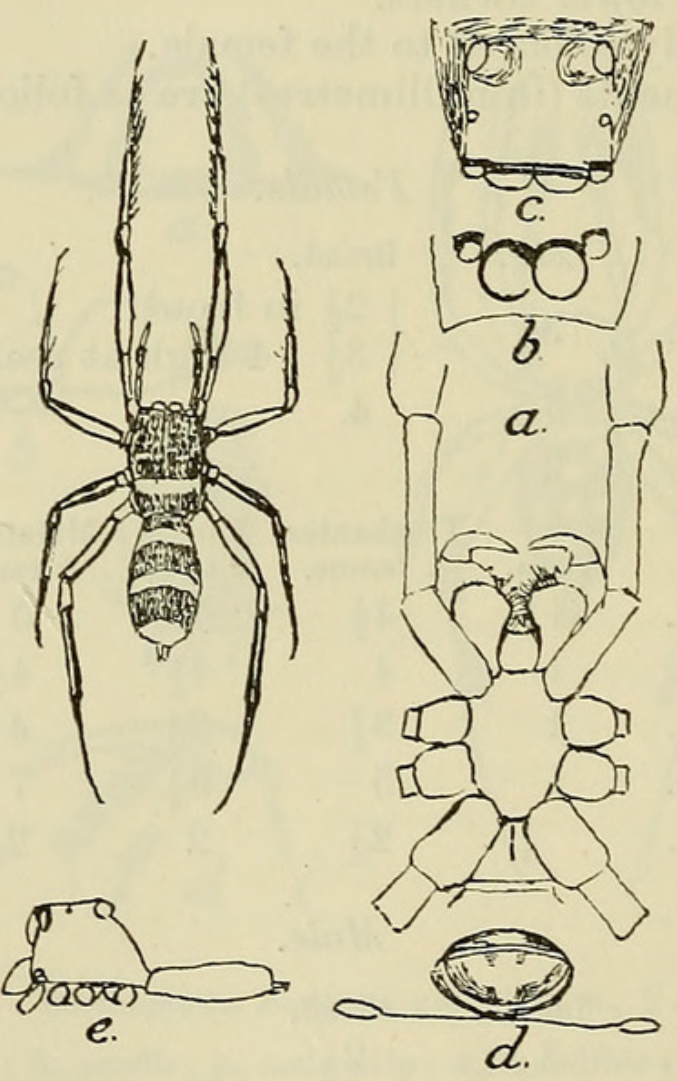

Diolenius albopiceus, sp. n., 우.

a., sternum, coxæ, and trochanters ; $b$., eyes from in front; $c$., eyes from above; d., epigyne; e., profile.

There are also three unbroken wide transverse stripes across the abdomen, one near the front, one in the middle, and one at the posterior end.

There are seven pairs of spines on round roots on the under side of tibia i., but no row of long hairs between them as in D. amplectens, and five pairs of spines under metatarsus i. 
The measurements (in millimetres) are as follows :-

Long. Broad.

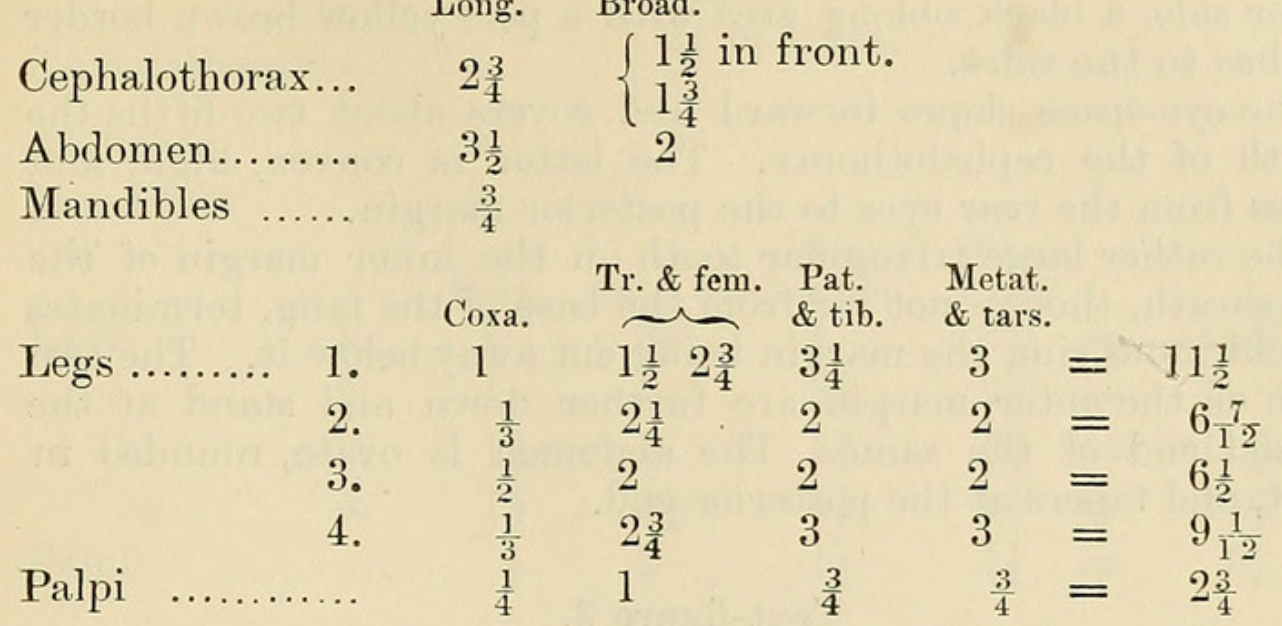

Of the half-dozen somewhat similar species described by Thorell from New Guinea and the neighbourhood, this is nearest to D. amplectens Thor. (Ragni Aust.-Malesi, 1881, p. 412 et seq.). It differs therefrom in having the front row of eyes more recurved, the line touching the upper edges of the median cutting the side eyes at a point near the lower margins; the diameter of the median is slightly more than twice that of the side eyes.

It differs from $D$. phrynoides Walck. in having the tibia of the front pair of legs cylindrical instead of club-shaped, and without any fimbriation on the under side.

D. fasciatus Thor., the coloration of which is somewhat similar, has (according to that author) eight pairs of stout spines under tibia $i$ and only two pairs under metatarsus i.

\section{Section Unidentatæ. \\ Group Chrysillew.}

Genus Telamonia Thor.

Thorell, Ann. Mus. Gen. ser. 2, vol. v. 1887, p. 385.

E. Simon, Hist. Nat. des Ar. vol. ii. 1901, p. 552.

Telamonia vidua, sp. n. (Text-fig. 3.)

1 female. (Type of the species.)

Female. The cephalothorax is black, sparsely covered with white squamous hairs and upright black and white bristles over the eye-space, on the clypeus they are greyish-white. The mandibles are black, paler about the falx-margin, the fangs dark red-brown. Lip, maxillæ, and sternum black-brown with greyish hair. The legs yellow-brown underneath, the coxæ quite bright yellow, but the first three pairs of femora are dark yellow-brown on the upper side. The abdomen is black above with upright grey hairs and bristles, a white area of squamous hairs at the base, and two 
similarly haired transverse bands broken in the middle, one about the middle and the other near the posterior end. On the under side, a black oblong area with a pale yellow-brown border reaches to the sides.

The eye-space slopes forward and covers about two-fifths the length of the cephalothorax. The latter is convex, high, and slopes from the rear eyes to the posterior margin.

The rather large triangular tooth on the inner margin of the falx-sheath, though not far from the base of the fang, terminates the chitinous rim, the margin being cut away below it. The two teeth on the outer margin are further down and stand at the normal end of the same. The abdomen is ovate, rounded in front, and taper's at the posterior end.

Text-figure 3 .

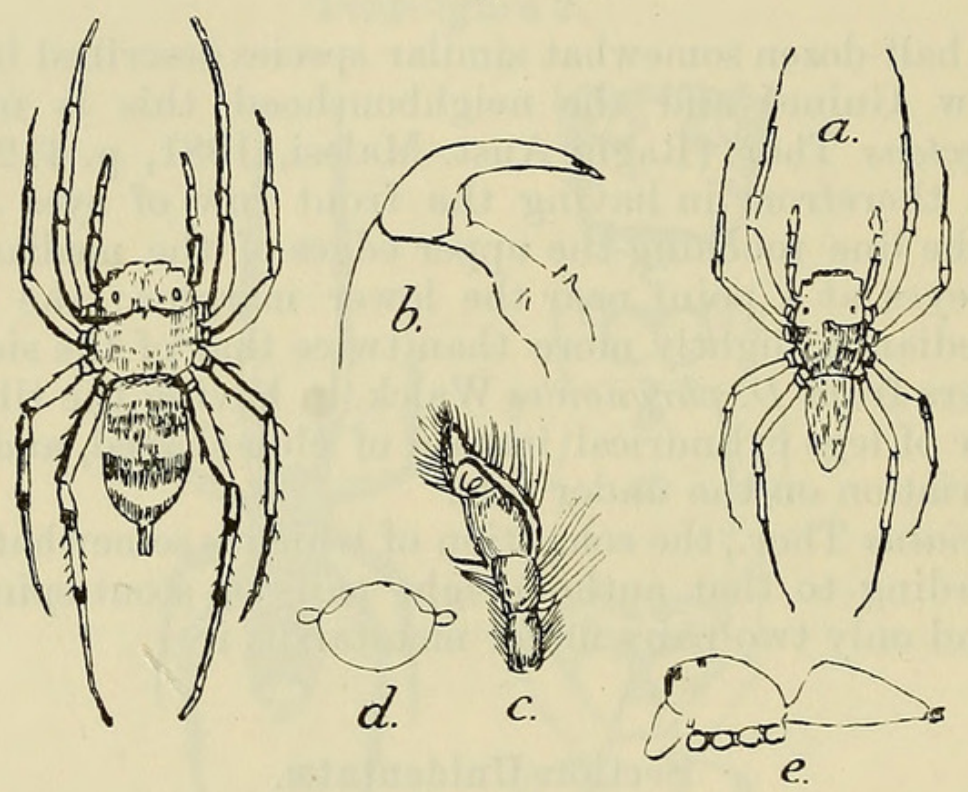

Telamonia vidua, sp. n.,

a., male?; $b$. , mandible showing teeth; $c$. , male palp; $d .$, epigyne; e., profile.

The rear row of eyes is not quite so broad as the front row, and narrower than the cephalothorax at the point where it crosses the latter. The front row is recurved; the side eyes half the diameter of the median, standing a little away from the latter. The lip is longer than broad; the maxillæ, upright, rounded anteriorly, and thickly covered with bristly hair, are less than twice as long as the lip. The sternum is ovate, truncate in front, where it is twice as wide as the base of the lip.

Under metatarsus i. are two pairs of spines, one near the base and another at the anterior end. There are two spines above on femur iv., one small on the outer side of the patella, two pairs on the tibia, two single ones on the outer side and a bunch at the anterior end of the metatarsus, all of moderate size. 
The measurements (in millimetres) are as follows :-

Long. Broad.

$\begin{array}{ll}\text { Cephalothorax... } & 4 \\ \text { Abdomen } \ldots \ldots & 5\end{array} \quad\left\{\begin{array}{l}2 \frac{1}{2} \text { in front. } \\ 3 \frac{1}{2}\end{array}\right.$

Mandibles $\ldots . . . \quad 2$

\begin{tabular}{ccccccc} 
& \multicolumn{7}{c}{ Coxa. } & Tr. \& fem. & $\&$ tib. & $\&$ tars. & \\
Legs …....... & 1. & 1 & $3 \frac{1}{2}$ & 4 & $3 \frac{1}{4}=$ & $11 \frac{3}{4}$ \\
& 2. & 1 & 3 & $3 \frac{1}{4}$ & $2 \frac{3}{4}=$ & 10 \\
& 3. & $1 \frac{1}{4}$ & 3 & $3 \frac{3}{4}$ & $3 \frac{3}{4}=$ & $11 \frac{3}{4}$ \\
& 4. & $1 \frac{1}{2}$ & $3 \frac{3}{4}$ & $4 \frac{1}{4}$ & $4 \frac{1}{4}=$ & $13 \frac{3}{4}$ \\
Palpi ….......... & $\frac{1}{2}$ & 2 & $1 \frac{1}{2}$ & $1 \frac{1}{4}=$ & $5 \frac{1}{4}$
\end{tabular}

Male. A somewhat broken specimen, almost similar in colouring to the above, appears to be of the same species but, as in other cases, the first pair of legs is the longest instead of the fourth. The shape of the cephalothorax and positions of the eyes are similar as also the falx-sheath teeth, but the lip is rather broader, making it as broad as long. The coxæ have thick white hairs at the ends adjoining the trochanters.

The white pattern on the back of the abdomen is formed of scales in two rows of rather large spots disposed longitudinally instead of transversely, and the pale bordering on the under side is less distinct than in the female. There is a row of eleven spines on the anterior half of tibia i. underneath as in T. trabifera Thor. and allied species.

The measurements (in millimetres) are as follows :-

Long. Broad.

Cephalothorax... $\quad 3 \frac{1}{2} \quad\left\{\begin{array}{l}2 \frac{1}{4} \text { in front. } \\ 2 \frac{1}{2}\end{array}\right.$

Abdomen......... $3 \frac{1}{2} \quad 1 \frac{1}{2}$

Mandibles ..... 1

Pat. Metat.

Coxa. Tr. \& fem. \& tib. \& tars.

\begin{tabular}{|c|c|c|c|c|c|c|}
\hline Legs & 1. & $1 \frac{1}{2}$ & $3 \frac{1}{2}$ & $3 \frac{1}{2}$ & 3 & $=$ \\
\hline & 2. & 1 & 3 & $2 \frac{1}{2}$ & $2 \frac{1}{4}$ & $=$ \\
\hline & 3. & 1 & $2 \frac{1}{2}$ & $2 \frac{1}{2}$ & $2 \frac{3}{4}$ & $=$ \\
\hline & 4. & 1 & 3 & $2 \frac{3}{4}$ & $3^{*}$ & $=$ \\
\hline Palpi & & $\frac{1}{2}$ & $1 \frac{1}{4}$ & $\frac{3}{4}$ & 1 & $=$ \\
\hline
\end{tabular}

In 'Ragni di Selebes,' p. 251, Dr. T. Thorell described a male from Kandari which he named Telamonia (Moevia C. L. Koch, 1848) latruncula. This is apparently very closely akin to the above female, but differs in having a white marginal fillet round the cephalothorax, and elsewhere being brightly coloured red, blue and green, and having the lip $1 \frac{1}{2}$ longer than broad. The

Proc. Zool. Soc.-1915, No. XXXV. 
legs are shorter, but in about the same proportion as in this female.

Either that or the above described male appears near enough to belong to the female, but of course the pair above described is known to be from the same neighbourhood.

Telamonia mandibulata, sp. n. (Text-fig. 4.)

1 male. (Type of the species.)

Male. Cephalothorax black-brown, with white squamules over the eye-space interspersed with a few upstanding black bristles ; the mandibles are black-brown. The lip and maxillæ brown with reddish fringes. The sternum dark brown with greyish-white

Text-figure 4 .

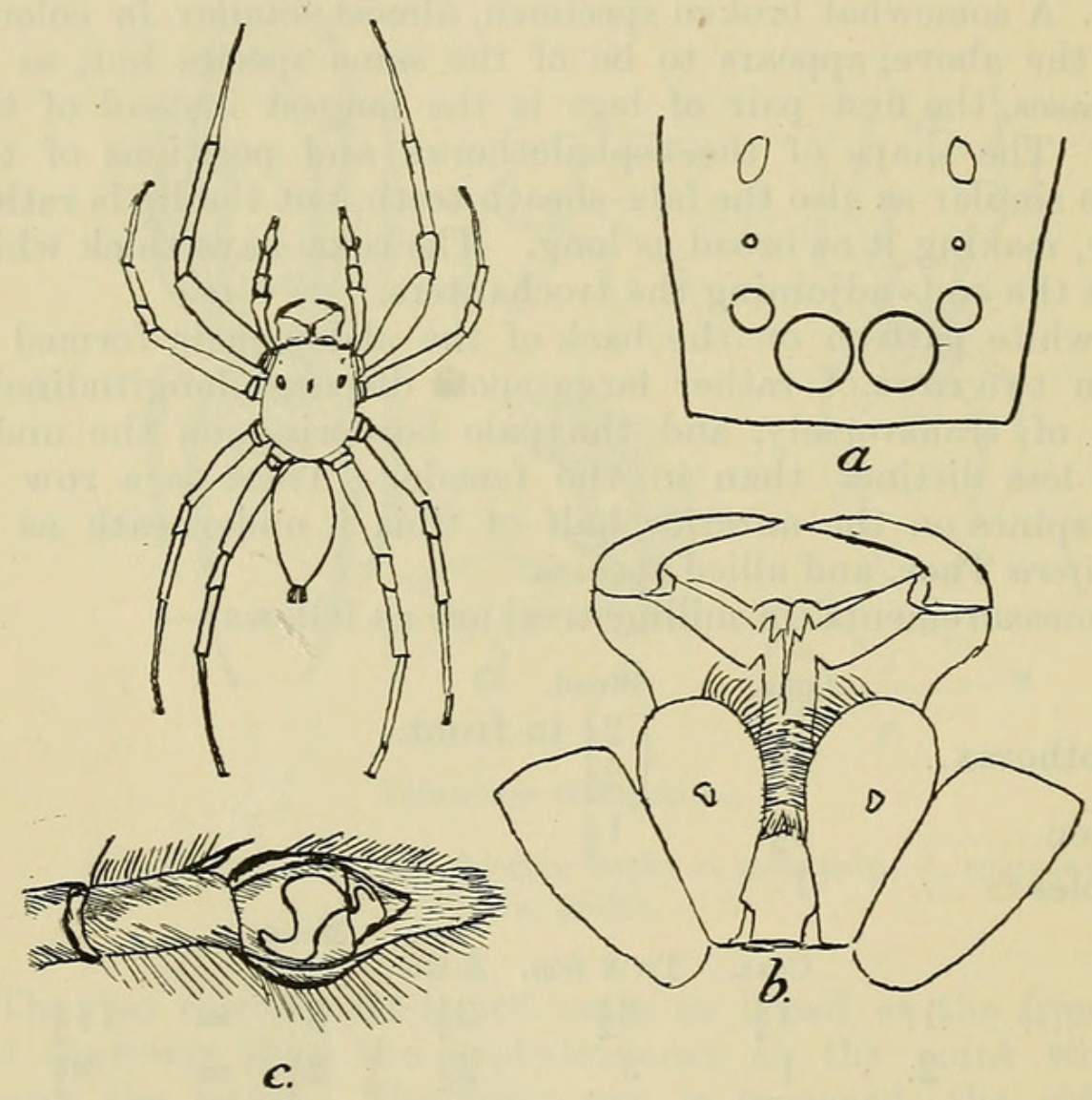

Telamonia mandibulata, sp. n., $\delta$.

$a$., eyes ; $b$., mandibles, lip, and maxillæ ; $c$., male palp.

hair. Of the coxæ, which are all contiguous, the first pair are brown, the remainder bright yellow. The abdomen is blackbrown on the upper side, with upstanding white bristly hairs and a fillet of white squamules round the base and sides; inside this are two rows of large spots of the same arranged longitudinally from a little before the middle to the rear end ; underneath it is a dull yellow-grey. The front pair of legs is brown all over 
with the exception of a pale yellow ring at the distal end of the tibial joint. The other legs are yellower. They are all sparsely furnished with white almond-shaped scales and upstanding pale yellow-brown hairs. The palpi are as dark as the first pair of legs.

The cephalothorax is about one-fifth longer than broad, flat on the eye-space, highest at the level of the rear row of eyes, whence it slopes slightly forward and steeply to the margin all round. The eye-space, broader than long, extends to nearly one-half the total length; it is slightly narrower at the rear than at the front. The eyes are all ringed with wide black margins. The small eyes of the median row are about midway between the rear and the front side eyes. The clypeus is one-third as wide as the diameter of the front median. The front row is recurved, the side eyes being slightly separated from the median which are close together.

The mandibles are perpendicular, convex on their outer side. At a short distance from their insertion below the clypeus they begin to widen out towards the anterior end, where they are twice their width at the base. The total thickness at the anterior end, in addition to the space between the inner and outer margins of the falx-sheath, comprises a superimposed raised area reaching from near the outer margin to the corner farthest away from the base of the fang, where it ends in a large prominence. Between this and the normal falx-sheath margin it is hollowed out. On this secondary outer margin is a small fringe. The usual falx-sheath is wide and deep, the inner margin terminating in a large conical tooth at its lower end, from here to the base of the falx the thickness is considerable.

The lip is longer than broad; rounded anteriorly and narrowed at the base for about one-fourth of its length, it is remarkably convex, the middle being a considerable height above the level of the margins. The maxillæ are upright, rounded anteriorly, narrowed at the base, about twice as long as the lip, and as broad as the latter is long. They are also very convex, being raised to the middle of their area in successively smaller layers, and terminating at their greatest convexity in a small boss.

The sternum is ovate, truncate anteriorly, where it is wider than the lip; the front coxæ are clearly longer than the others.

The abdomen is ovate, with rather long terminal spinnerets.

There are two spines above on femora i. and ii. One weak spine on the inside of each patella, one pair at the base of tibia i., two single on the outer side, and a row of eleven on the anterior half of the inner side of the same. Four pairs under tibia ii., one pair and an anterior bunch on metatarsus ii.

The tibial apophysis of the palp is broad at the base but tapers to a fine point. The distal joint is short and broad near the base, rounded at the sides and square at the anterior end, with a short stigma springing from a hollow above the bulb. The patella is as long as the tibia. 
The measurements (in millimetres) are as follows :-

\begin{tabular}{|c|c|c|c|c|c|c|c|}
\hline \multicolumn{2}{|c|}{ Cephalothorax... } & $\begin{array}{l}\text { Long. } \\
\qquad 4 \frac{1}{2}\end{array}$ & $\begin{array}{l}\text { Broad. } \\
3 \text { in } \mathrm{f} \\
3 \frac{1}{2}\end{array}$ & ont. & & & \\
\hline \multirow{2}{*}{\multicolumn{2}{|c|}{$\begin{array}{l}\text { Abdomen......... } \\
\text { Mandibles ...... }\end{array}$}} & $4 \frac{1}{2}$ & $2 \frac{1}{2}$ & & & & \\
\hline & & $2 \frac{1}{2}$ & & & & & \\
\hline egs ... & 1. & $\begin{array}{c}\text { Coxa. } \\
1 \frac{1}{2}\end{array}$ & $\begin{array}{c}\text { Tr. \& fem. } \\
4 \frac{1}{2}\end{array}$ & $\begin{array}{l}\text { tib. } \\
5\end{array}$ & $\begin{array}{l}\text { M tars. } \\
4 \frac{1}{2}\end{array}$ & $=$ & $15 \frac{1}{2}$ \\
\hline & 2. & 1 & $3 \frac{1}{2}$ & $3 \frac{1}{2}$ & 3 & $=$ & 11 \\
\hline & 3 & 1 & $3 \frac{1}{2}$ & $3 \frac{1}{2}$ & 4 & $=$ & 12 \\
\hline & 4. & $1 \frac{1}{4}$ & 4 & 4 & $4 \frac{1}{2}$ & $=$ & $13 \frac{3}{4}$ \\
\hline $\operatorname{lpi} \ldots .$. & & $\frac{1}{2}$ & 2 & $1 \frac{1}{2}$ & $1 \frac{1}{2}$ & $=$ & $5 \frac{1}{2}$ \\
\hline
\end{tabular}

The legs are of about the same proportion as those of $T$. scalaris Thor. from Ternate. The species resembles $T$. trabifera Thor. and some others in the row of 11 spines on the side of tibia $i$. (Thorell, Ragni Austro-Mal. 1881, pp. 477 \& 480), but differs from all in the extreme convexity of the lip and maxillæ, and the shape of the mandibles.

Group SAITEe.

Genus Jotus Koch.

Jotus L. Koch, Die Arach. Austr. 1881, p. 1243.

Jotus Igneus, sp. n. (Text-fig. 5.)

1 male, 1 female. (Types of the species.)

Female. The cephalothorax is pale red-brown, moderately thickly covered with recumbent yellowish-white hair and on the eye-space with upright white bristles; round the margin of the front eyes are fillets of curly white bristles and much longer ones of the same colour on the clypeus.

The mandibles are yellow-brown, darkest on the anterior margins, with the fangs brown at the base and pale red at the anterior half.

The lip and maxillæ are orange with dark yellow fringes, the sternum and coxæ paler yellow with yellowish-grey hair. The legs are bright yellow, the front pair being rather the darkest.

The abdomen above is pale yellow, with smooth silky white hair. Along each side a row of large brown spots forms a broken line nearly continuous at the rear end: on the under side is a wedge-shaped brown area extending from the genital fold to just above the spinnerets. The front and sides are the same colour as the upper side. The spinnerets and basal portion of the epigyne are darker yellow.

The front row of eyes is recurved, slightly wider than the rear row, which is narrower than the cephalothorax at that part, and the small median are midway between the rear eyes and the front laterals. 
The single flat triangular tooth, about the middle of the inner falx-sheath margin, is particularly large, and the anterior tooth of the outer margin is also rather large.

There is a row of three short spines in front of each femur above, with two single spines about the middle. On the under side of tibia i. and ii. are three pairs of long powerful spines and two smaller spines on the inner side; on metatarsus i. and ii. underneath are two pairs of long spines; on metatarsus iii. and iv. are a pair near the base and a bunch at the anterior end, and on tibia of same two above, two on the side, and a pair underneath. On the femoral joint of the palp are two spines, on the patella one on each side, on the tibia one above, and on the distal joint one below.

Text-figure 5 .

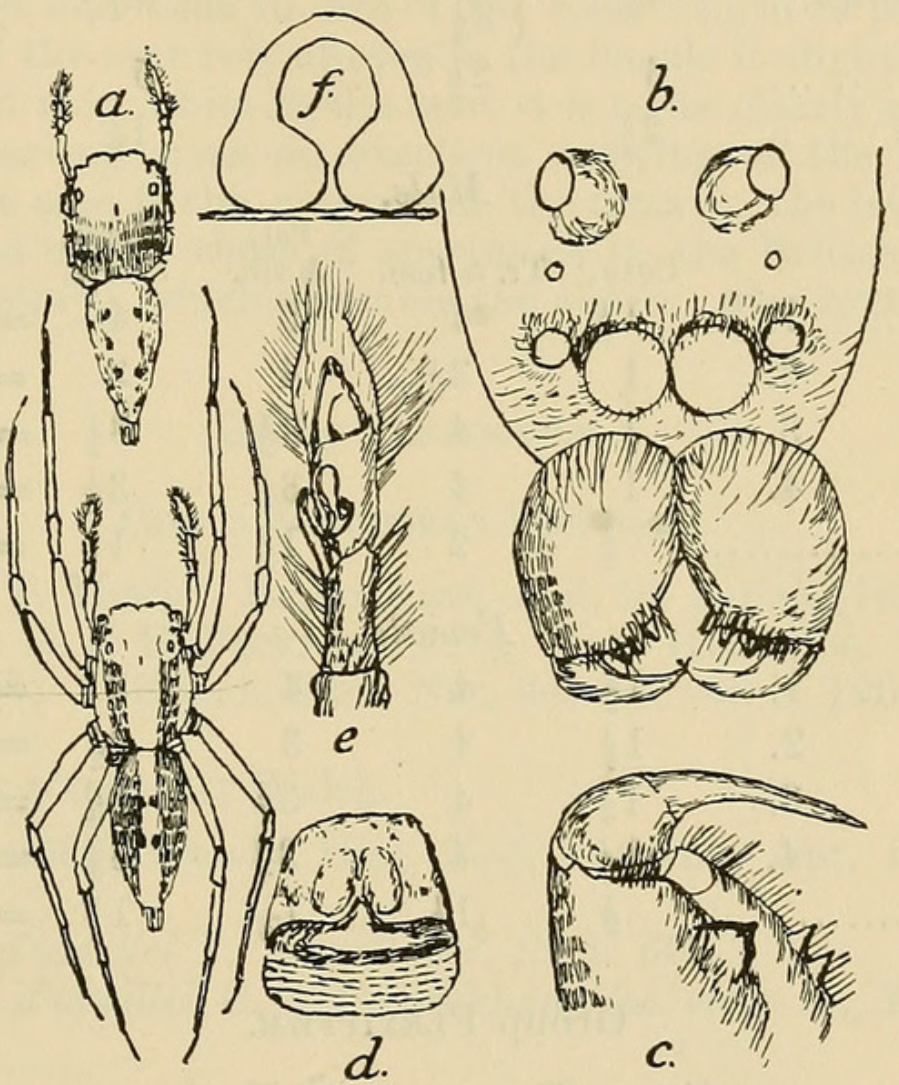

Jotus igneus, sp. n., ठే.

$a$., female; $b$., eyes and mandibles of female; $c$., mandible showing teeth of male; $d$., epigyne of female; e., male palp; $f$., Plexippus paykulli, epigyne of female.

Male. Similarly coloured to the female, the sides of the cephalothorax being, however, darker brown and the brown stripes on the abdomen continuous; the brown area on the under side also begins quite at the base. On the front pair of legs the femora are darker than on those of the others. The distal end of the tibiæ and metatarsi are also rather darker.

The male palp is of the same pattern as that of $J$. auripes L. Koch, but the epiphysis is not serrated, nor are the bristly hairs 
nearly so thick and long. The pattern of the cephalothorax differs in having pale median and marginal stripes, with a darker yellow-brown area between, instead of black, and the median area on the upper side of the abdomen pale instead of dark. Its larger size also distinguishes it from the former.

It will be seen from the measurements below that in the male the first pair of legs is longest, while in the female it is the fourth pair. There is no appreciable difference in the length of the tibia and patella iii. and iv. in the female, while in the male those joints in the fourth pair are only very slightly longer.

The measurements (in millimetres) are as follows :-

Male.

Long. Broad.

Cephalothorax... $\quad 4 \frac{1}{2} \quad\left\{\begin{array}{l}3 \text { in front. } \\ 3 \frac{1}{4} \\ 2 \frac{1}{2}\end{array}\right.$

Abdomen........ $6 \quad 2 \frac{1}{2}$

Mandibles $\quad \ldots . . \quad 2 \frac{1}{4}$

\section{Male.}

Coxa. Tr. \& fem. \& tib. Metat.

\begin{tabular}{|c|c|c|c|c|c|c|}
\hline Legs & 1. & $\begin{array}{r}\text { Coxa. } \\
1 \frac{1}{2}\end{array}$ & $\begin{array}{c}\text { Tr. \& fem. } \\
4\end{array}$ & $\begin{array}{c}\& \text { tib. } \\
5\end{array}$ & $\begin{array}{c}\& \text { tars. } \\
4\end{array}$ & $=$ \\
\hline & 2. & 1 & $3 \frac{1}{2}$ & 4 & 3 & $=$ \\
\hline & 3. & 1 & 4 & $3 \frac{1}{2}$ & $3 \frac{1}{2}$ & $=$ \\
\hline & 4. & 1 & 4 & $3 \frac{3}{4}$ & $3 \frac{1}{2}$ & $=$ \\
\hline lni & & $\frac{1}{2}$ & 2 & $1 \frac{1}{2}$ & $1 \frac{\tilde{1}}{4}$ & $=$ \\
\hline
\end{tabular}

\section{Female.}

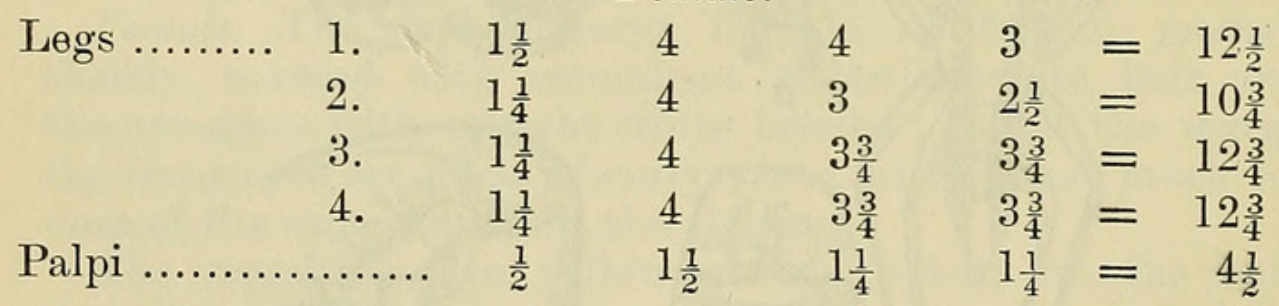

\section{Group Plexippea.}

Genus Plexippus C. Koch.

Plexippus C. Koch, Ueb. Ar. Syst. v. 1850, p. 51. (Ad part. $P$. ligo $=P$. paykullii Aud.)

Plexippus paykullit Aud. (Text-fig. $5, f$.)

Attus paykullii Aud. in Sav. Desc. de l'Égypte, $2^{\mathrm{e}}$ Edit. 1827, vol. xxii. p. 172 ; l. c. pl. vii. fig. 22 , folio. ? 1826 .

Salticus culicivorus C. L. Doleschall, Tweede Bijd. Arach. van den Ind. Archip. p. 14, pl. ix. fig. 5 : Act. Soc. Sci. Indo-Néerl. vol. v. 1858-9.

Menemerus culicivorus T. Thorell, Ragni Selebes, 1877, p. 228 ; id., Ragni Amboina, 1878, p. 237 ; id., Ragni Austro-Mal. 1881, p. 508. 
Menemerus paykulli Keyserling, Die Arach. Aust. 1883, p. 1425, pl. cxxiii. fig. 4.

Plexippus paykulli T. Thorell, Ragni Indo-Mal. 1891-2, p. 369.

1 male and 3 females.

Collected from Spain and Africa; also, according to various authorities, round the world eastwards and, according to F. O. P. Cambridge, in S. America.

It is impossible to compare Doleschall's drawing of $S$. culicivorus with a recognised female specimen of P.paykulli without feeling that it must have been drawn from the same, and Thorell apparently arrived at this conclusion (Ragni Indo-Mal. 1892, p. 370). In his description, which is quite short, Dr. Doleschall says that the legs are in the order 4321 , while it is certain that the second pair is the shortest.

The patella and tibia iii. are of the same length as patella and tibia iv., and the rear row of eyes in the female is slightly shorter than the first row, while in the male it is quite clearly so.

Von Keyserling gives an excellent drawing of the male and adds what he says is the epigyne of the female; the latter, however, is quite unlike those of specimens in the British Museum (Natural History), which resemble the above. (See text-fig. 5, f.)

\section{Group Zenodorex.}

\section{Genus Zenodorus Peckham.}

Ephippus T. Thorell, Ragni Aust.-Mal. iii. p. 643 (1881).

$Z$ enodorus G. \& E. Peckham, Proc. Nat. Hist. Soc. Wisc. vi. p. 287 (1885); E. Simon, Hist. Nat. des Ar. vol. ii. 1901, p. 656.

Zenodorus D'URVILLII Walck.

Attus d'urvillii Walck. Hist. Nat. des Ins. Apt. i. p. 459 (1837).

Ephippus d'urvillei T. Thorell, loc. cit. p. 653.

Zenodorus d'urvillei G. \& E. Peckham, loc. cit.; id., E. Simon, loc. cit.

1 male.

This male seems clearly to belong to this species, agreeing with Thorell's elaborate description, and showing the first pair of legs longest, though not so long in proportion as in some later described species. The mandibular tooth on the inner margin is conical and quite large if the soft basal portion is taken into consideration, and only "very minute" if you reckon the point alone, which is darker and harder. The mandibles are hollowed out in the middle of the inner side, much corrugated, and the stout base of the short curved fang occupies the whole of the anterior end of the falx.

A raised flat rim at the front of the clypeus seems a feature in this genus Zenodorus; it is not quite so well defined in the female as in the male. 
The measurements (in millimetres) are as follows :Long. Broad.

$\begin{array}{ll}\text { Cephalothorax... } & 4 \\ \text { Abdomen......... } & 5 \\ \text { Mandibles ....... } & 2\end{array} \quad\left\{\begin{array}{l}2 \frac{1}{2} \text { in front. } \\ 3 \frac{1}{2} \\ 2 \frac{1}{2}\end{array}\right.$

\begin{tabular}{|c|c|c|c|c|c|c|c|}
\hline \multirow{5}{*}{ Legs } & & Coxa. & Tr. \& fem. & $\begin{array}{l}\text { Pat. } \\
\text { \& tib. }\end{array}$ & $\begin{array}{l}\text { Metat } \\
\text { \& tars. }\end{array}$ & & \\
\hline & 1. & $1 \frac{1}{2}$ & 4 & $2, \quad 3 \frac{1}{2}$ & $2 \frac{1}{2}, \quad 1$ & $=$ & $14 \frac{1}{2}$ \\
\hline & 2. & $1 \frac{1}{4}$ & 3 & $2 \frac{1}{2}$ & $2 \frac{1}{4}$ & $=$ & 9 \\
\hline & 3. & 1 & 4 & $1, \quad 2 \frac{1}{2}$ & $2 \frac{1}{4}, \quad \frac{3}{4}$ & $=$ & $11 \frac{1}{2}$ \\
\hline & 4. & $1 \frac{1}{4}$ & 3 & $\frac{3}{4}, \quad 2 \frac{1}{4}$ & $2, \quad 1$ & $=$ & $10 \frac{1}{4}$ \\
\hline Palpi & & $\frac{1}{2}$ & 2 & 1 & $1 \frac{1}{2}$ & $=$ & 5 \\
\hline
\end{tabular}

Zenodorus danae, sp. n. (Text-fig. 6.)

8 males and 10 females. (Including the types of the species.)

Female. Cephalothorax black-brown, with very brilliant green, red, and yellow iridescent scales at the sides and rear of the eye-space, with a few scattered here and there between the eyes

Text-figure 6 .
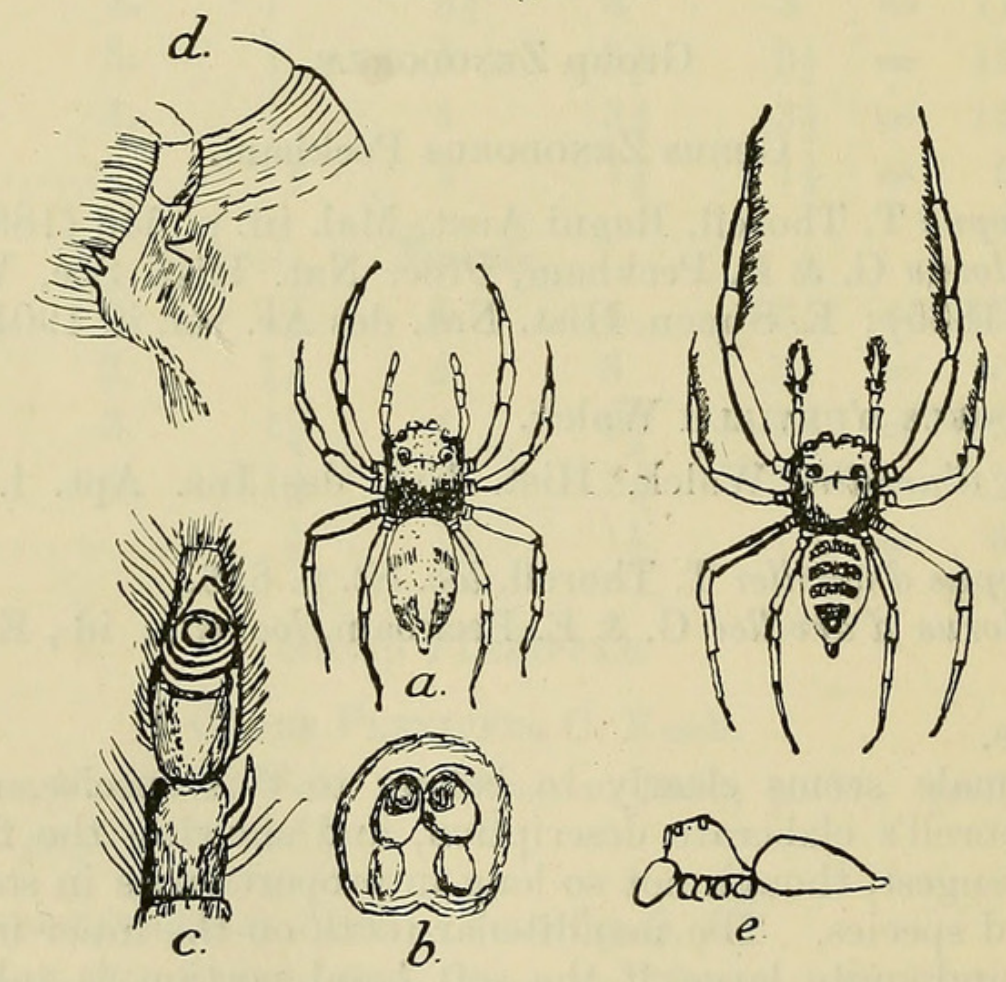

Zenodorus danae, sp. n., ठే.

$a$., female; $b$., epigyne; $c$., male palp; $d$., mandible showing teeth ; e., profile.

and on the clypeus. The mandibles, lip, and maxillæ are dark red-brown with brown bristles and upright, flat, club-shaped, pearly-white iridescent hairs. The sternum, though dark, is more yellow-brown, with pale grey hair.

The legs and palpi are bright orange-yellow, with brown spines 
and bristles. The two rear pairs of legs darken into yellow-brown on the upper surface of the tibial and metatarsal joints. The abdomen is black-brown on the upper side; on the basal area, along the sides of the rear half, and in a procurved fillet across the middle, is a pattern formed of the green, red, and golden scales.

The under side is pale yellow-brown without any pattern.

The eye-space is two-fifths of the total length of the cephalothorax; the rear row is as broad as the front row, which is recurved; the cephalothorax at the rear row of eyes, its broadest part, considerably exceeds them in breadth. The clypeus is less than one-half the diameter of the front median eyes and terminates in a thick flat marginal rim. The mandibles are short, stout, and conical, the fang very thick at the base; on the inner margin of the falx-sheath the chitinous rim is continued only a short way down as far as a conical tooth; this, though rather small, is not "very minute," and below it the side is hollowed away. On the outer margin are two points on a single base and a thick fringe of bristles. The lip is as broad as long, rounded anteriorly, half the height of the maxillæ, which are upright, convex, broad, and rounded on the outer side. The first pair of coxæ, slightly wider apart than the breadth of the lip, are longer than any of the others.

The abdomen is oval, about twice as long as broad.

There are two pairs of stout spines on the under side of metatarsus i. and similar smaller ones under metatarsus ii.

Three pairs of spines under tibia i. with two single spines on the inner side. One on each patella. On femora iii. and iv. there are 1, 1 spines above, and numerous spines on the tibiæ and metatarsi.

On the inner side of the patella, tibia, and metatarsus i. there is a thick fringe of bristles.

The front pair of legs are stouter than the others.

The vulva consists of two broad oval depressions side by side, separated by a narrow ridge with two other shallower and smaller foveæ below the first pair, the whole on an elevated, rather square area.

The measurements (in millimetres) are as follows :-

\begin{tabular}{|c|c|c|c|c|c|c|}
\hline \multirow{3}{*}{$\begin{array}{l}\text { Cephalothorax... } \\
\text { Abdomen.......... } \\
\text { Mandibles ...... }\end{array}$} & $\begin{array}{c}\text { Long. } \\
5\end{array}$ & \multirow{3}{*}{\multicolumn{2}{|c|}{$\begin{array}{l}\text { Broad. } \\
3 \text { in front. } \\
4 \\
3 \frac{1}{2}\end{array}$}} & & & \\
\hline & 6 & & & & & \\
\hline & 2 & & & & & \\
\hline Legs . & $\begin{array}{c}\text { Coxa. } \\
1 \frac{1}{4}\end{array}$ & $\begin{array}{c}\text { Tr. \& fem. } \\
4\end{array}$ & $\begin{array}{l}\text { Pat. } \\
\& \text { tib } \\
4\end{array}$ & $\begin{array}{c}\text { Metat. } \\
\& \text { tars. } \\
3\end{array}$ & $=$ & $12 \frac{1}{4}$ \\
\hline 2 & 1 & $3 \frac{1}{2}$ & 3 & $2 \frac{1}{2}$ & $=$ & $10^{4}$ \\
\hline 3 & l & 4 & 4 & $3 \frac{1}{2}$ & $=$ & $12 \frac{1}{2}$ \\
\hline 4 & 1 & $3 \frac{1}{2}$ & 3 & $3 \frac{1}{2}$ & $=$ & 11 \\
\hline$\ldots \ldots \ldots \ldots$ & $\frac{1}{2}$ & $1 \frac{3}{4}$ & $1 \frac{1}{2}$ & $1 \frac{1}{4}$ & $=$ & \\
\hline
\end{tabular}


This species would seem to be rather close to $Z$. julia Thor. (l. c. p. 650), which it resembles apparently in the pattern of brilliant scales on a black ground and the form of the epigyne, but differs from it in the much more even lengths of the legs, the third pair in $Z$. julia exceeding the first and fourth by $2 \frac{1}{2}$ and $3 \frac{1}{2}$ millimetres respectively, and being also darker in colouring.

It is much paler in colour, larger, and the legs $\mathrm{i}$. and iii. are nearer the same length, than in Mr. Pocock's $Z$. variatus (Willey, New Britain, etc., vol. i. 1899, p. 117). It differs also from $Z$. d'urvillei (Walck.) in the much brighter colouring and absence of rings on the legs, while the pattern of the epigyne differs from that drawn by Von Keyserling (Die Arach. Aust. pl. exx. fig. $4 d$ ).

Males. In most respects these agree so closely with the females described above and are represented by so nearly the same number of specimens in the present collection, that it is difficult to avoid the conclusion that they are males of the same species. The chief difference is that the front pair of legs are much longer than the others, a fact which does away with one of the characteristics of the genus, in which the third pair of legs are said to be much longer than the others. Were it not, however, for the special enlargement of the first pair, the third would be the longest.

The clypeus is not quite so broad as the diameter of the front median eyes, the rear row is as broad as the front row. The eye-space slopes forward, and from the hinder row the thoracic part slopes steeply to the rear margin.

The mandibles are flatter than in the female, both the outer and inner sides being strongly corrugated transversely. The tooth on the upper margin is of moderate size; the inner margin of the falx-sheath is cut away to about one-third of the length of the outer margin and exists only for a short distance near the base. The lip is as broad as long, rounded in front, hollowed out on either side of the base, and transversely corrugated. The sternum is three-fourths as wide as it is long, truncated in front, and the coxæ are as far apart as the greatest width of the lip. The male palp has a flagellum in about three spirals at the anterior end of a plain oval bulb.

The front pair of legs is strongly fimbriated on the under side of the patellar, tibial, and metatarsal joints. The cephalothorax and abdomen are black-brown, with a pattern of opalescent pearly scales.

Under metatarsus i. are two pairs of stout spines, but none at the side. Three pairs under tibia i. One spine each on patellæ iii. and iv., and a bunch at the anterior end of metatarsi iii. and iv. 
The measurements (in millimetres) are as follows :-

Long. Broad.

Cephalothorax... $\quad 5 \quad\left\{\begin{array}{l}3 \frac{1}{2} \text { in front. } \\ 5\end{array}\right.$

Abdomen......... $6 \quad 3 \frac{1}{2}$

Mandibles ...... 3

Coxa. Tr. \& fem. \& tib. \& \& tars.

$\begin{array}{rrrrccc}\text { Legs ......... } & 1 . & 2 \frac{1}{2} & 7 & 2 \frac{1}{2}, 5 \frac{1}{2} & 3 \frac{1}{2}, 1 \frac{1}{2}= & 22 \frac{1}{2} \\ & 2 . & 1 \frac{3}{4} & 4 & 4 & 3 \frac{1}{2} & =13 \frac{1}{4} \\ 3 . & 1 \frac{1}{2} & 5 & 2,2 \frac{1}{2} & 3 \frac{1}{2}, 1 & = & 15 \frac{1}{2} \\ 4 . & 1 \frac{1}{2} & 4 & 4 & 4 & = & 13 \frac{1}{2} \\ \text { Palpi .............. } & \frac{3}{4} & 2 & 1 \frac{1}{2} & 1 \frac{1}{2}= & 5 \frac{3}{4}\end{array}$

Zenodorus rhodope, sp. n. (Text-fig. 7.)

2 males and 2 females. (Including the types of the species.)

Males with one tooth on inner margin of falx-sheath.

Females with two teeth on inner margin of falx-sheath.

Female. The cephalothorax is dark yellow-brown on the

Text-figure 7 .

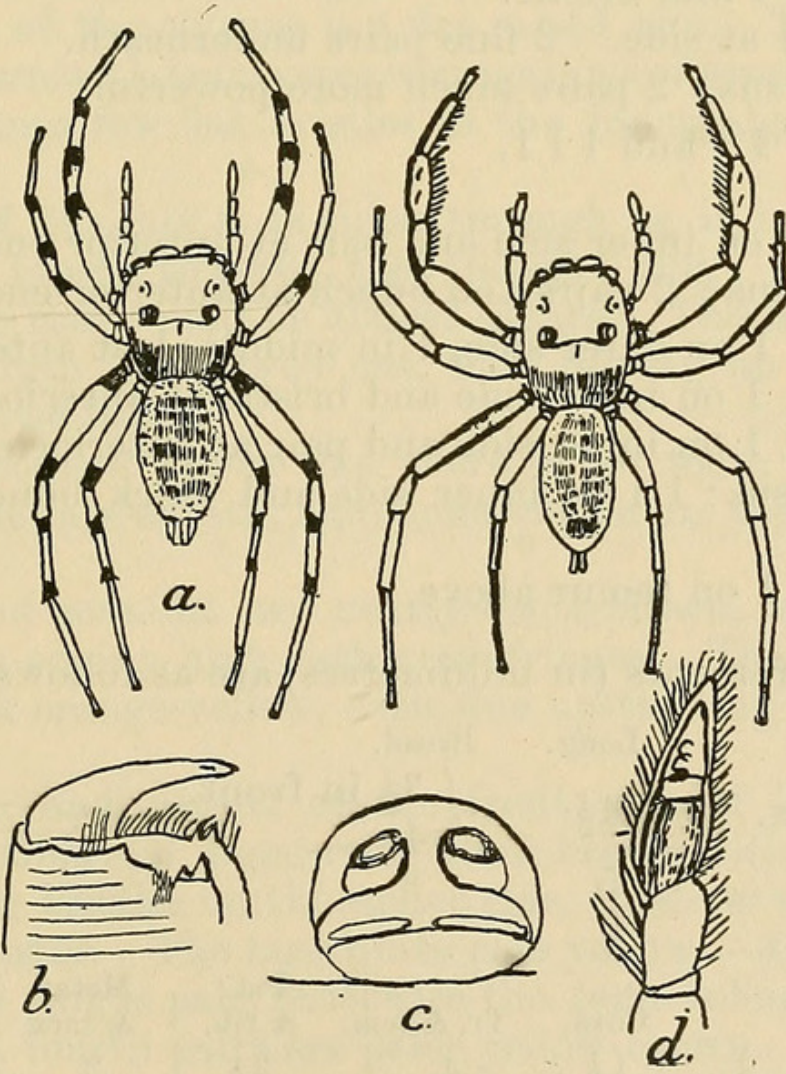

Zenodorus rhodope, sp. n., ठే.

a., female; $b$., mandible showing teeth ; $c$., epigyne; $d$., male palp.

cephalic part; all the eyes on large black tubercles. Small white lancet-shaped scales and upright brown bristles spread at 
intervals about the eye-space. The thoracic part is nearly blackbrown to the sides of the posterior margin. On the clypeus are long white upstanding bristles.

The mandibles are dark red-brown, with a paler patch at the lower inner margin of the falx. The fangs red-brown. The lip and maxillæ dark brown, yellow-brown at the margin with yellowish-brown fringes. The sternum is yellow-brown. The coxæ bright yellow. Legs and palpi as described for $Z$. syrinx.

The abdomen on the upper side is dark greyish-brown, covered round the sides and base thickly, in the central area more sparsely, with pearly-white squamules and upstanding brown normal hairs. On the under side it is much more thickly covered with short, upstanding, white bristly hair; the spinnerets are the same; the epigyne dark yellow.

Arrangement of spines on the legs :-

I. Femur: 111 above and 111 small at anterior end. Patella: 1 on inner side and long bristle.

Tibia: 3 pairs underneath.

Metatarsus : 2 pairs very long and stout on under side.

II. Femur : 11 above and 111 at anterior end on inner side, 11 on outer.

Patella: 1 and bristle.

Tibia.: 1 at side. 2 fine pairs underneath.

Metatarsus : 2 pairs much more powerful.

III. Femur : 11 and 111 .

Patella: 1 .

Tibia : 1 on inner side and pair at anterior end.

Metatarsus : 2 pairs and bunch at anterior end.

IV. Femur: 1 on outer side, 1 in middle, 1 at anterior end.

Patella: 1 on inner side and bristle at anterior end.

Tibia : 11 on inner side and pair at anterior end.

Metatarsus : 11 on inner side and thick bunch at anterior end.

Palp : 11 on femur above.

The measurements (in millimetres) are as follows :-

Long. Broad.

\begin{tabular}{|c|c|c|c|c|c|c|c|}
\hline \multirow{2}{*}{\multicolumn{8}{|c|}{ Cenhalothorax }} \\
\hline & & & & & & & \\
\hline \multirow{2}{*}{\multicolumn{2}{|c|}{$\begin{array}{l}\text { Cephalothorax... } \\
\text { Abdomen ......... } \\
\text { Mandibles ..... }\end{array}$}} & 5 & 3 & \multirow[b]{3}{*}{$\begin{array}{l}\text { Pat. } \\
\& \text { tib. } \\
3 \frac{1}{2}\end{array}$} & \multirow[b]{3}{*}{$\begin{array}{c}\text { Metat. } \\
\& \text { tars. } \\
3\end{array}$} & \multirow[b]{3}{*}{$=$} & \multirow[b]{3}{*}{12} \\
\hline & & 2 & & & & & \\
\hline \multirow{2}{*}{ Legs . ......... } & 1. & $\begin{array}{c}\text { Coxa. } \\
1 \frac{1}{2}\end{array}$ & $\begin{array}{l}\text { Tr. \& fem. } \\
\quad 4\end{array}$ & & & & \\
\hline & 2. & $1 \frac{1}{4}$ & 3 & $3^{2}$ & $2 \frac{1}{2}$ & $=$ & $9 \frac{3}{4}$ \\
\hline & 3. & $1 \frac{1}{4}$ & 5 & 4 & $4 \frac{\tilde{1}}{2}$ & $=$ & $14 \frac{3}{4}$ \\
\hline & 4. & $1 \frac{1}{4}$ & 4 & 3 & 4 & $=$ & $12 \frac{1}{4}$ \\
\hline Palpi....... & $\ldots$ & 1 & $1 \frac{1}{2}$ & $1 \frac{1}{4}$ & $1 \frac{1}{4}$ & $=$ & 5 \\
\hline
\end{tabular}


The females are rather more highly coloured than the males and the legs more distinctly ringed, but so closely resemble them in structure and general coloration that I have supposed them to be of the same species, though unless captured together the matter is always open to doubt.

In the males the tooth on the inner falx-sheath is raised above the lower end of a straight base, which in the females has a point at the other end also, enough to make it really fissidentated; but these two and the following $Z$. syrinx with no teeth at all are all so much alike, and so distinctly resemble Zenodorus d'urvillei, the type species, that I am unable to separate them from that genus.

\section{Zenodorus syrinx, sp. n. (Text-fig. 8.)}

1 male and 1 female. (Types of the species.)

Male without teeth on falx-sheath.

Female without teeth on inner margin of falx-sheath.

Male. Cephalothorax black-brown on the eye-space, bright red-brown just behind the same, behind this again dark brown to the rear margin; scattered over this at intervals are lanceolate pearly scales, more thickly at the sides and on the clypeus, where some of them are lengthened into flat bristles. On the front margin of the clypeus is a flat raised rim. The mandibles are black-brown with transverse corrugations of green opalescence, and, except for a few flat bristles at the inner edge of the base, quite bare.

The base of the falx is as thick through as it is broad transversely, but tapers towards the anterior end. A transverse section at the base would be almost square. The median part of the inner margin is hollowed out, thus leaving an oval opening between the two falces.

In the specimen before me there is no tooth on the lower margin of the falx-sheath, and none visible in the thick fringe on the outer.

The lip and maxillæ are nearly black-brown, with a narrow yellow-brown edging and dark grey fringes. The sternum and coxæ are dark orange-yellow, with fine upstanding yellow-brown hair.

The femur and patella of the front pair of legs are dark orange; the tibia and metatarsus black-brown with a thick black fringe of long bristles on the under side, those on the metatarsus being the shorter. The tarsi quite pale yellow. The metatarsus of the second pair is pale, otherwise the same colour as the first; the third and fourth pairs are paler yellow-brown.

The abdomen on the upper side is dark greyish-brown, with short upstanding brown hair over the basal area; following this is a broad field of pearly-grey scales, and along the sides patches of the same as far as the spinnerets; the under side is pale yellowish-grey. 


\section{Text-figure 8.}
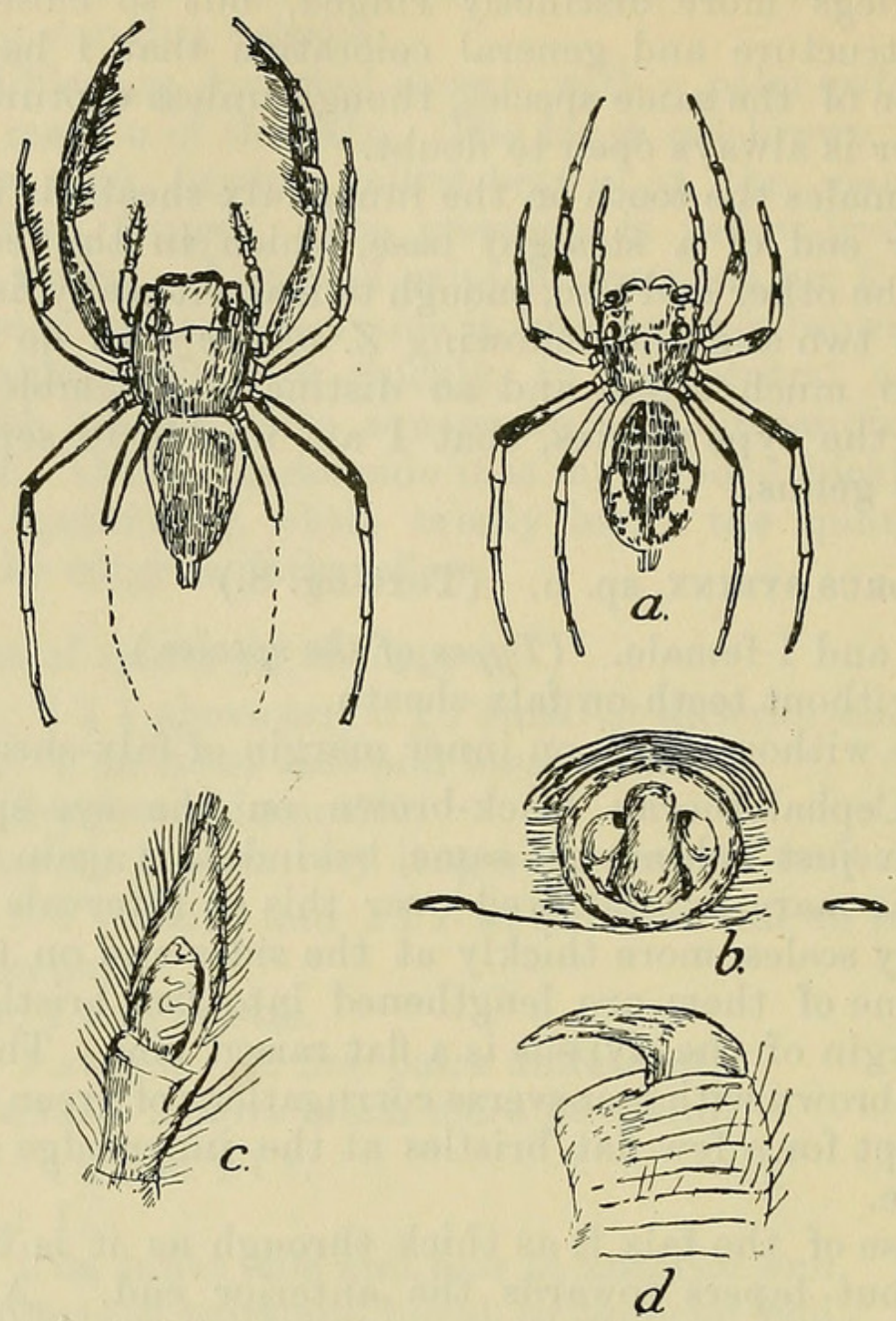

Zenodorus syrinx, sp. n., ठิ.

$a$. female; $b$., epigyne ; $c$., male palp; $d$., mandible.

The measurements ${ }_{\triangle}$ (in millimetres) are as follows :-

Long. Broad.

Cephalothorax... $5 \quad\left\{\quad\left\{\begin{array}{l}3 \text { in front. } \\ 3 \frac{1}{2}\end{array}\right.\right.$

Abdomen......... $2 \quad 2 \frac{1}{2}$

Mandibles $\ldots . . . \quad 2$

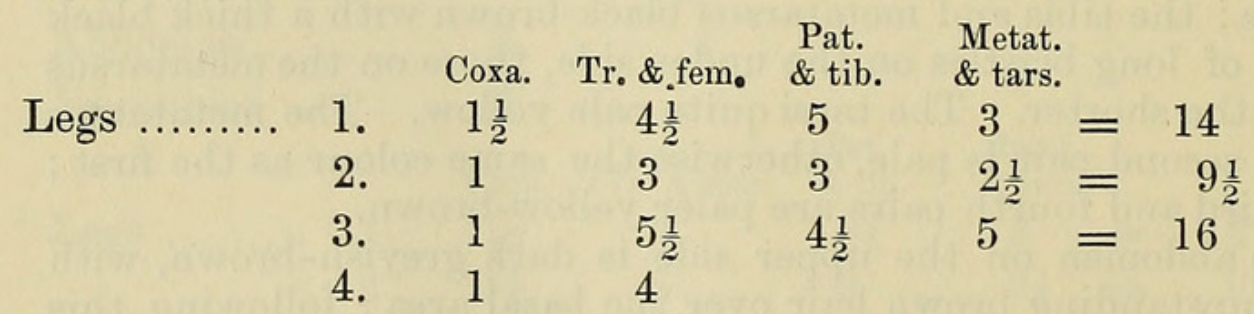

Female. Cephalothorax dark yellow-brown; all the eyes on large black tubercles. Long brown bristles and short white 
lancet-shaped scales spread here and there. The mandibles black-brown with red-brown fangs and brown fringe. A paler patch just below the lower corner of the falx-sheath. The lip and maxillæ are dark yellow-brown with paler edgings. The sternum pale yellow-brown, with upstanding brown bristles and pale yellow-grey hair. The coxæ bright yellow. The whole of the palp the same, with upstanding yellowish-grey bristles. The basal half of the femora of all the legs is bright yellow-brown, the anterior half brown; patella and tibia yellow-brown, metatarsus and tarsus orange-yellow.

The abdomen is black, with a fillet of white squamous hairs round the base reaching along each side to half the length of the abdomen. From the end of this on each side are three large white spots continuing the line to the spinnerets; on the under side it is plain greyish-yellow; the hairs all ordinary, very fine, pale yellow. The spinnerets rather long, conical, and darker brown, on a white chitinous base half their length, have long straight brown hair and a short cylindrical second joint.

The inner margin of the falx-sheath is cut away and hollowed out to the outer margin, at the lower end of which are two moderate-sized teeth. The inner side of the falx-sheath itself is also hollowed out, most deeply about the middle.

The lip is as broad as long, truncate and slightly hollowed anteriorly, half the length of the maxillæ, which are convex, upright, rounded anteriorly. The front coxæ are farther apart than the lower margin of the lip is wide. The sternum ovate, truncate, and narrowest in front, is flat at the anterior end for one-third of its length and thence to the posterior end convex.

The epigyne consists of two oval hollows resting against the upper part of a broad longitudinal convex septum; below these hollows and fitting into the lower part of the same central septum are two chitinous triangular cushions. The whole inside an oval frame.

Arrangement of spines on the legs :-

On femur i. \& ii. above are single spines 11 , and a row of three small on the inner side at the anterior end.

On patella i. \& ii. a short spine on the inner side and a very long bristle at the anterior end.

On tibia i. \& ii. three pairs on the under side.

On metatarsus i. \& ii. two pairs (very stout) on the under side.

On patella iii. \& iv. one small on inner side and a very long bristle at distal end.

On tibia iii. \& iv. one small pair below at the anterior end, and two single on inner side.

On metatarsus iii. \& iv. one small underneath about the middle, and bunch at anterior end.

On metatarsus iii. two single at the side, but none on iv. 
The measurements (in millimetres) are as follows :Long. Broad.

Cephalothorax... $\quad 3 \quad\left\{\begin{array}{l}3 \text { in front. } \\ 3 \frac{1}{2} \quad 4 \text { high. }\end{array}\right.$

$\begin{array}{ll}\text { Abdomen.......... } & 5 \frac{1}{2} \\ \text { Mandibles ...... } & 2\end{array}$

Pat. Metat.

Coxa. Tr. \& fem. \& tib. \& tars.

\begin{tabular}{|c|c|c|c|c|c|c|}
\hline Legs ......... & 1. & $1 \frac{1}{4}$ & $3 \frac{1}{4}$ & $3 \frac{1}{4}$ & $2 \frac{1}{2}$ & $=$ \\
\hline & 2. & 1 & $2 \frac{1}{2}$ & $2 \frac{1}{2}$ & 2 & $=$ \\
\hline & 3. & 1 & $4 \frac{1}{2}$ & $3 \frac{3}{4}$ & $3 \frac{1}{2}$ & $=$ \\
\hline & 4. & 1 & $3 \frac{1}{4}$ & 3 & $3 \frac{1}{2}$ & $=$ \\
\hline & & & 7 & & & \\
\hline
\end{tabular}

This species differs from $Z$. rhodope in having no teeth on the falx-sheath margin, in not having the legs ringed, slight differences in the male palp and epigyne of the female, and in the spines as detailed, but otherwise the two species closely resemble one another.

\section{Group Thyeneж.}

Genus Mopsus Karsch.

Mopsus Karsch, Mittheil. Münchener Entom. Vereins, vol. ii. 1878, p. 31.

\section{Mopsus mormon Karsch.}

Mopsus mormon Karsch, loc. cit.; T. Thorell, Ragni AustroMalesi, p. 462 (1881).

Ascyltus penicillatus Keyserling, Die Arach. Aust. p. 1319, pl. cxii. (1882).

Mopsus mormon Keyserling, loc. cit. p. 1475 (1883).

1 male and 2 females.

Previously recorded from New Guinea, Cape York, Bowen, Rockhampton, and Sydney.

\section{Group Plexippea.}

Genus Bathippus Thor.

Bathippus Thorell, Ragni Indo-Malesi, pt. iv. vol. ii., 1891-2, p. 401 ; E. Simon, Hist. Nat. des Ar. vol. ii. 1903, p. 740.

Bathippus montrouzieri, var. PAPUANus Thor.

Plexippus montrouzieri Lucas, Revue et Mag. de Zool. 1869, p. 209, pl. xi. figs. 8-12 ; Thorell, Ragni Austro-Malesi, iii. 1881, p. 526 .

6 males.

Previously recorded from Wokan, Aru Islands, and Fly River, New Guinea. 


\section{Section Fissidentati. \\ Group Hasariee.}

Genus Hasarius Simon.

Hasarius E. Simon, Hist. Nat. des Ar. vol. ii. 1903, p. 795.

Hasarius glaucus, sp. n. (Text-fig. 9.)

1 female. (Type of the species.)

Female. The cephalothorax is orange-yellow, black between the side eyes; mandibles, lip, maxillæ, sternum, and legs all pale yellow, with nearly white hairs and grey spines.

The abdomen above is dark grey at the sides with short recumbent white hairs, a broad pale area at the base, and a pale yellowgrey scolloped longitudinal stripe down the middle. On the under side the median area is the darker, the sides being pale yellow-grey. The spinnerets are yellow, springing from a long white chitinous base nearly as long as themselves. The epigyne is rather dark yellow.

Text-figure 9.
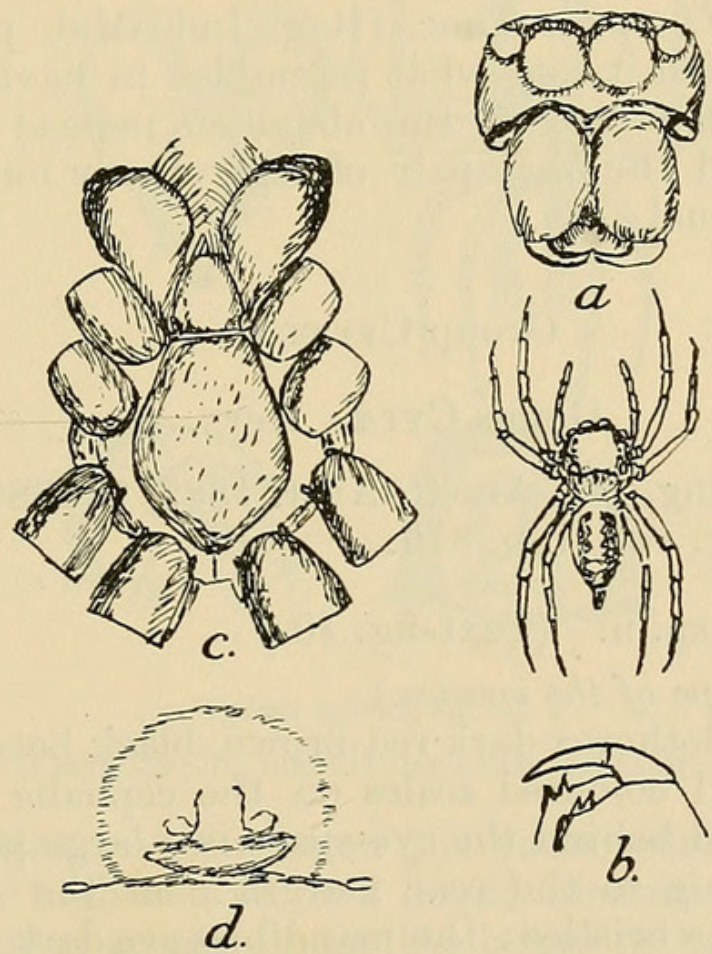

Hasarius glaucus, sp.n., $\varsubsetneqq$.

a., front eyes and mandibles ; $b$., mandibular teeth and fang; $c$. lip, maxillæ, sternum, and coxæ; $d$., epigyne.

The eye-space is spread over two-thirds of the cephalothorax. The lip is longer than broad. Sternum ovate, truncate, and narrowest in front; the third coxa is isolated from the sfcond and fourth.

On the under side of tibia i. are two pairs of long spines, one Proc. Zool. Soc.-1915, No. XXXVI. 
pair of short ones at the anterior end, and two single spines on the outer side; underneath the metatarsus there are three pairs (two very long) and a bunch at the anterior end.

Two single spines above and two pairs on metatarsus iii. and iv.; under tibia iii. and iv., a pair of fine spines in the middle and another at the anterior end.

The measurements (in millimetres) are as follows :-

$$
\text { Long. Broad. }
$$

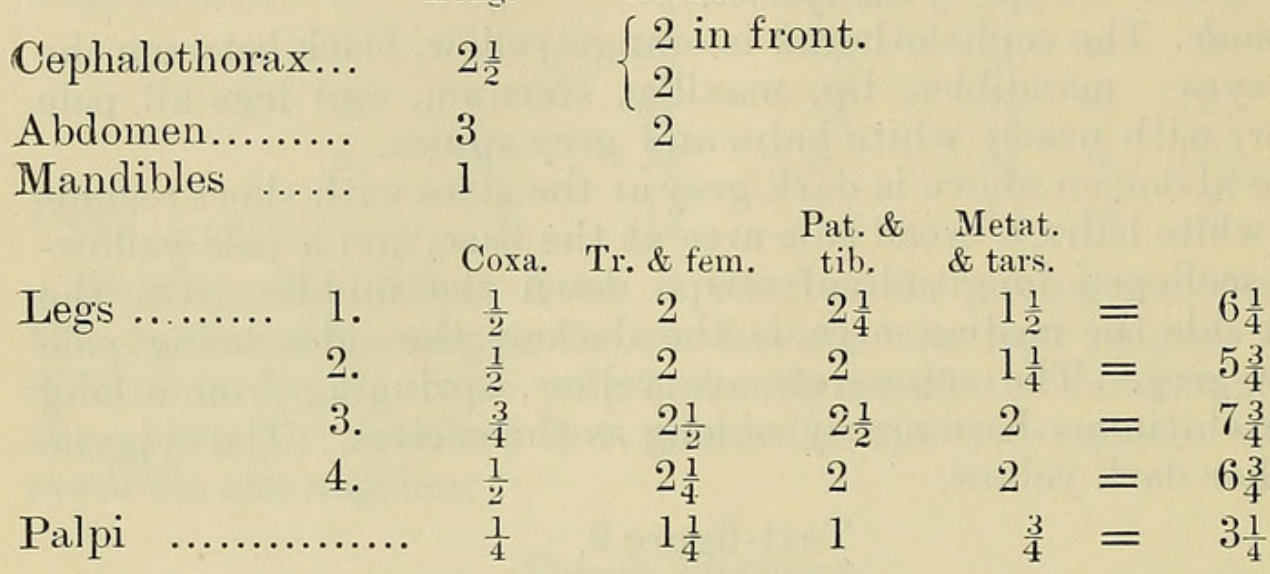

Differs from $H$. coprea Thor. (Rag. Indo-Mal. pt. iv. vol. ii. 1892, p. 434), which it somewhat resembles in having a longitudinal pale median stripe on the abdomen instead of transverse black streaks, and the hind pair of legs clearly longer than the first instead of equal.

\section{Group CyTæe}

\section{Genus Сутæa Keys.}

Cytcea Keyserling, Die Arach. Aust. 1882, p. 1380 ; E. Simon, Hist. Nat. des Ar. vol. ii. p. 816.

Cytea sylvia, sp. n. (Text-fig. 10.)

1 female. (Type of the species.)

Female. Cephalothorax dark red-brown, black between the side eyes. White and coloured scales on the cephalic part. On a lighter red ground behind the eye-space is a large patch of white squamules reaching to the rear margin; on the clypeus is a bush of long white bristles; the mandibles are dark brown on the inner margin, pale chestnut-red on the outer sides and brown underneath. The fangs red, paler at the points. The lip and maxillæ are brown on the lower and middle parts, yellow over a rather wide area in front. The sternum and coxæ are pale yellow with white upstanding hair. The two front pairs of legs have the femora pale red-brown on the upper side with a dark brown patch at the anterior end, and dark brown on the under side, thickly covered with white squamules on the pale portions, and with coloured squamules on the darker parts. The patella and tibia are pale and dark brown in alternate rings; the 
metatarsus and tarsus pale yellow-brown; the two posterior pairs of legs are somewhat paler, but with similar brown rings and squamules intermixed with upstanding brown bristles. The palpi are yellow-brown, with thick brushes of long white bristles.

The ground-colour of the abdomen is pale yellow, covered with thick masses of white, black, and red lancet-shaped scales all mixed up together.

The eye-space and thoracic part each occupies about one-half of the total length of the cephalothorax, but, the upper flat part continuing for about halfway on the thoracic, the rear slope is quite steep at the end.

The front row of eyes is straight along the upper edges, the rear eyes about the same diameter as the front lateral. The second row of eyes halfway between these two are quite small; the clypeus about one-fourth the diameter of the front median eyes.

Text-figure 10.

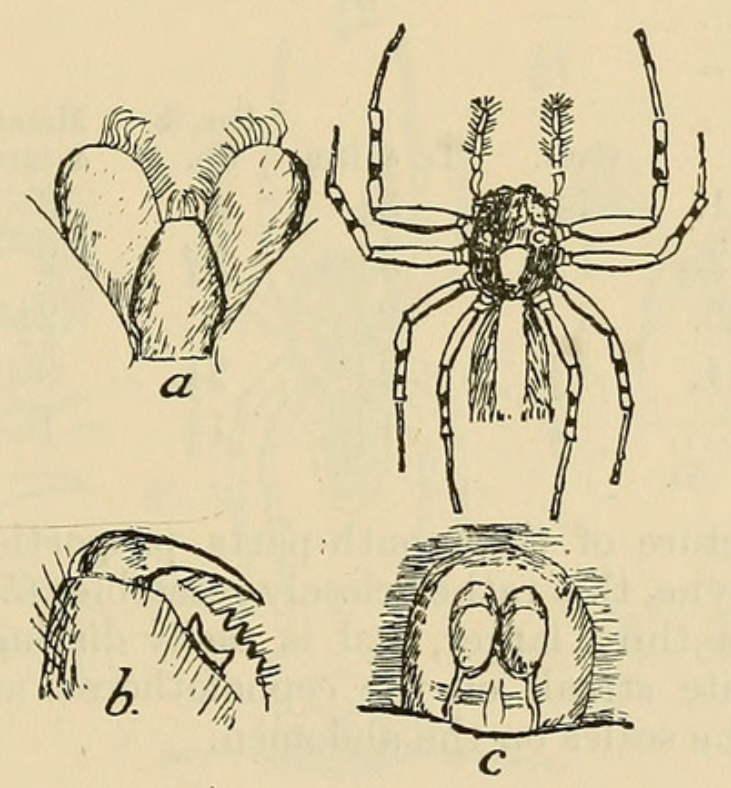

Cytraa sylvia, sp. n., 우.

$a$., lip and maxillæ; $b$., mandibular teeth and fang; $c$., epigyne.

The mandibles are convex on the outer side. The fissidental tooth is rather high and its own length distant from the base of the fang, its lower corner forms the larger of two conical teeth; on the outer margin are four teeth, the two upper being largest and the lower quite small.

The lip is clearly longer than broad, narrowed and rounded in front, and more than half the length of the maxillæ. The front coxæ are barely separated by the distance of the breadth of the base of the lip, so that the sternum is narrower in front than at the posterior end ; it is ovate, convex over the posterior twothirds, with a broad flat margin between it and the coxæ. The abdomen is oval, but is partially destroyed. The epigyne consists of a pair of deep oval depressions upright, side by side, separated by a black chitinous ridge widest in the middle, which runs 
round the upper and lower edges and inner side ; the upper part of each of these depressions is covered over with a light sort of deck, dark streaks run down from their lower ends to the genital fold, and the whole stands on a raised area arched anteriorly.

In the middle of the upper side of each femur is a single spine and a row of four abreast at the anterior end; on each patella one spine each side; under all the metatarsi are three pairs of spines, on the inner side two single and on the upper side a pair near the base followed by a single. Under metatarsus i. and ii. two pairs of very long spines, and two single on the inner side; on metatarsus iii. two bunches of spines; on metatarsus iv. one pair underneath, one above, two at the side, and a bunch at the anterior end.

The measurements (in millimetres) are as follows :-

Long. Broad.

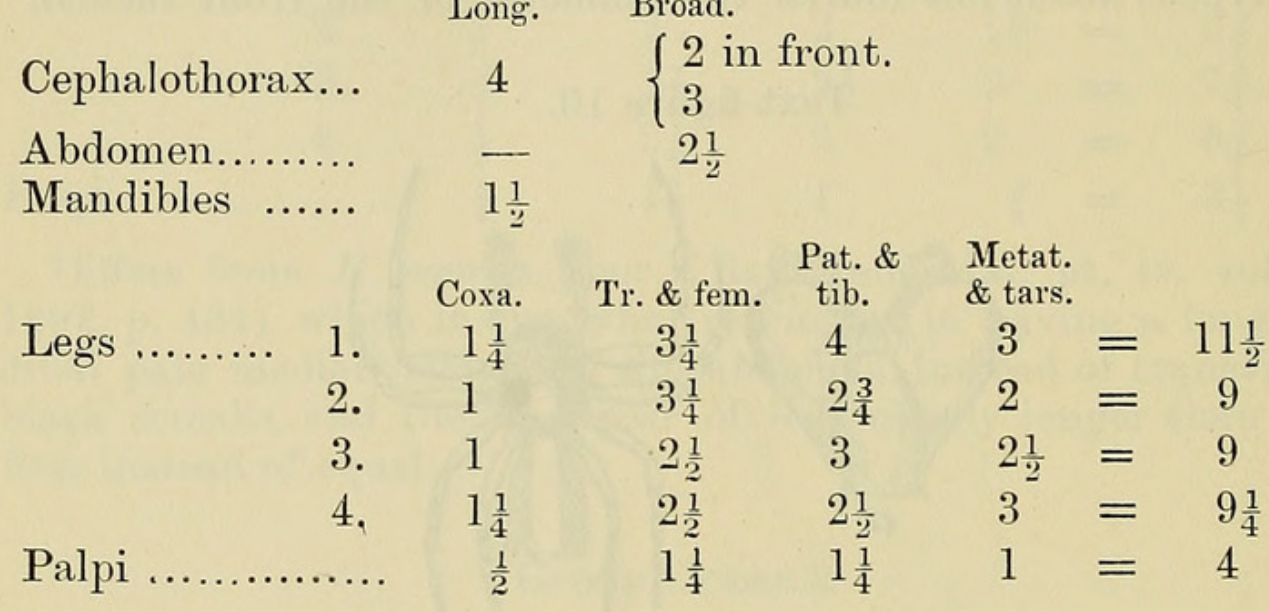

In the structure of the mouth-parts, proportion of legs, and pattern of epigyne, this rather closely resembles $C$. alburna Keys. It is at least a third larger, and is easily distinguished by the prominent white streak on the cephalothorax and the bright coloration of the scales on the abdomen.

Cytea laodamia, sp. n. (Text-fig. 11.)

1 male and 2 females. (Including the types of the species.)

Female. Cephalothorax black-brown with greyish-white squamules and brown bristles, reddish bristles between the front eyes, and thick long white bristles on the clypeus. Mandibles black-brown with red-brown fangs. Lip, maxilla, sternum, and coxæ dark brown, the fringes on the former brown and short upstanding greyish-white hair on the remainder. The abdomen on the upper side is brown over the median area, with a white fillet of squamous hairs at the base and down each side as far as the spinnerets; the brown area has also white squamules in patches mingled with brown, and a more or less distinct median line of the same running down the anterior half: on the under 
side it is brown at the sides and yellow-grey in the central area with the same pale squamules. The femora, patellæ, and tibiæ of the legs are brown thickly covered with greyish squamules: the metatarsi are dark brown at the base and in front, with a yellow ring in the middle, and the tarsi yellow. The palpi are likewise brown, with white squamules on the upper surface, and long white bristly fringes on the sides of the patellar, tibial, and distal joints, smooth underneath.

The epigyne is greenish-grey in the central area, pale brown round the sides.

The spinnerets are pale brown, and spring from a conjoined chitinous base as high as one-half of their length. The bifid tooth on the inner falx-sheath stands out high, hollowed in the centre, the two ends form large flat conical teeth. There are three medium-sized teeth on the outer margin. The lip is convex, rounded anteriorly, but is hollowed out from nearly

Text-figure 11.

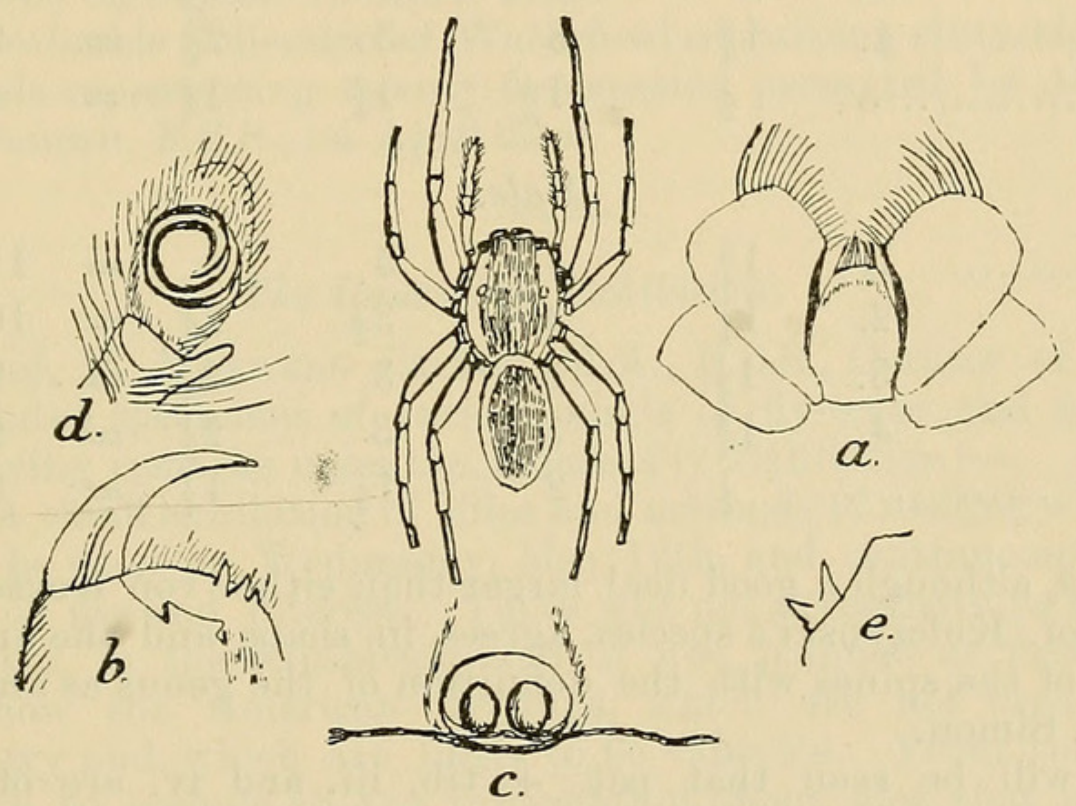

Cytaa laodamia, sp. n., ㅇ. .

$a$. lip and maxillæ; $b$., mandibular teeth and fang of male; $c$., epigyne; $d$., male palp ; e., inner mandibular teeth of female.

halfway down to the lower corners; this part being continuous with the rest, leaves it as wide at the base as it is high-it is rather more than half the length of the maxillæ. The sternum is oval, and while it narrows to the width of the convex portion of the lip, the front coxæ are as far apart as the full distance between the next pair.

Male. Similarly coloured to the female, but the upper side of the patellar and tibial joints are paler red-brown, and the fringe on the under side of the palpal distal joint darker brown. 
The bifid mandibular tooth on the inner margin is longer than in the previously described species, less distinctly shaped at the corners, and slightly serrated in the middle.

The measurements (in millimetres) are as follows :-

\section{Female.}

Long. Broad.

Cephalothorax... $\quad 4 \quad\left\{\begin{array}{l}2 \frac{1}{2} \text { in front. } \\ 3\end{array}\right.$

Abdomen......... $4 \frac{1}{2} \quad 2 \frac{1}{2}$

Mandibles $\quad . . . . \quad 1 \frac{1}{2}$
Male.

Long. . Broad.

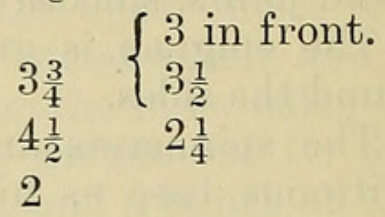

Female.

Coxa. Tr. \& fem. \& $\begin{gathered}\text { Pat. Metat. } \\ \text { \& tars. }\end{gathered}$

\begin{tabular}{|c|c|c|c|c|c|c|c|}
\hline Legs & 1. & $1 \frac{1}{2}$ & 3 & $3 \frac{1}{2}$ & 3 & $=$ & 11 \\
\hline & 2. & 1 & 3 & $2 \frac{1}{2}$ & 2 & $=$ & $8 \frac{1}{2}$ \\
\hline & 3. & 1 & 3 & 3 & $2 \frac{1}{2}$ & $=$ & $9 \frac{1}{2}$ \\
\hline & 4. & $1 \frac{1}{4}$ & 3 & 3 & $2 \frac{1}{2}$ & $=$ & $9 \frac{3}{4}$ \\
\hline Palpi & $\ldots$ & $\frac{1}{2}$ & $1 \frac{1}{2}$ & $1 \frac{1}{4}$ & $1 \frac{1}{4}$ & $=$ & $4 \frac{1}{2}$ \\
\hline
\end{tabular}

\section{Male.}

$\begin{array}{ccrllll}\text { Legs ......... } & 1 . & 1 \frac{3}{4} & 4 & 5 & 4 & =14 \frac{3}{4} \\ & 2 . & 1 \frac{1}{4} & 3 & 3 \frac{1}{2} & 2 \frac{1}{2}=10 \frac{1}{4} \\ & 3 . & 1 \frac{1}{4} & 3 & 3 & 2 \frac{1}{4}= & 9 \frac{1}{2} \\ & 4 . & 1 \frac{1}{4} & 3 & 3 . & 2 \frac{1}{2}=9 \frac{3}{4} \\ \text { Palpi } & . . . \ldots \ldots \ldots \ldots & \frac{1}{2} & 2 & 1 \frac{1}{2} & 1 \frac{1}{4}=5 \frac{1}{4}\end{array}$

This, although a good deal larger than either von Keyserling's or Prof. Kulczynski's species, agrees in shape and the arrangement of the spines with the definition of the genus as amplified by M. Simon.

It will be seen that pat. + tib. iii. and iv. are of equal length, in which it differs from $C$. alburna Keys. as well as in the pattern of the epigyne and general coloration.

The form of the epigyne is the same as that given by Prof. Kulczynski for his C. subsiliens, and, as in that species, the eye-area, although considerably broader than long, is still longer than the pars thoracica. It differs from the latter in the third and fourth pairs of legs being shorter than the first, instead of longer. 


\section{$2 \mathrm{BHL}$ Biodiversity Heritage Library}

Hogg, H R. 1915. "On spiders of the family Salticidae collected by the British Ornithologists' Union Expedition and the Wollaston Expedition in Dutch New Guinea." Proceedings of the Zoological Society of London 1915, 501-528.

View This Item Online: https://www.biodiversitylibrary.org/item/98466

Permalink: https://www.biodiversitylibrary.org/partpdf/69953

\section{Holding Institution}

Smithsonian Libraries

\section{Sponsored by}

Biodiversity Heritage Library

\section{Copyright \& Reuse}

Copyright Status: Public domain. The BHL considers that this work is no longer under copyright protection.

This document was created from content at the Biodiversity Heritage Library, the world's largest open access digital library for biodiversity literature and archives. Visit BHL at https://www.biodiversitylibrary.org. 